\title{
Direct determination of arsenobetaine and total As in robalo fish liver and tuna fish candidate reference material by slurry sampling graphite furnace atomic absorption spectrometry (SLS-GF AAS)
}

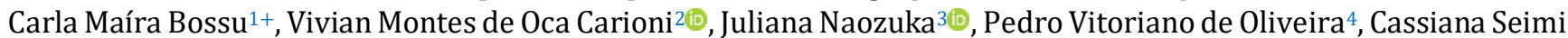
Nomura 4 (10

1 São Paulo State University (Unesp), Institute of Chemistry, 55 Prof. Francisco Degni St, Araraquara, São Paulo, Brazil

2 University of Missouri (MU), Research Reactor Center, 1513 Research Park Dr, Columbia, Missouri, United States of America

3 Federal University of São Paulo (Unifesp), 275 Prof. Artur Riedel St, Diadema, São Paulo, Brazil

4 University of São Paulo (USP), Institute of Chemistry, 748 Prof. Lineu Prestes Hw, São Paulo, São Paulo, Brazil

+Corresponding author: Carla Maíra Bossu, email address: carla.bossu@gmail.com

\section{ARTICLE INFO}

Article history:

Received: October 21, 2018

Accepted: January 9, 2019

Published: April 25, 2019

\author{
Keywords: \\ 1. arsenic \\ 2. direct chemical speciation \\ 3. tuna fish \\ 4. robalo liver \\ 5. reference material
}

ABSTRACT: This work describes a simple and rapid screening method for direct speciation of arsenobetaine (AsB) in tuna fish tissue and total As in tuna fish tissue and robalo liver using SLS-GF AAS. All procedures were proposed after careful optimization of pyrolysis and evaluation of chemical modifiers. Best results for total As were acquired using $25 \mu \mathrm{g} \mathrm{Pd}+15 \mu \mathrm{g} \mathrm{Mg}+0.1 \% \mathrm{w} / \mathrm{v}$ Triton X-100 in tuna fish $\left(4.4 \pm 0.3 \mathrm{mg} \mathrm{kg}^{-1}\right)$ and $100 \mu \mathrm{g} \mathrm{Pd}+0.1 \% \mathrm{w} / \mathrm{v}$ Triton X-100 solution in robalo liver $\left(10.3 \pm 0.6 \mathrm{mg} \mathrm{kg}^{-1}\right)$ as chemical modifiers. The direct speciation of AsB $\left(3.6 \pm 0.4 \mathrm{mg} \mathrm{kg}^{-1}\right)$ in tuna fish was achieved when $5 \mu \mathrm{g} \mathrm{Pd}+3 \mu \mathrm{g} \mathrm{Mg}+0.1 \%$ w/v Triton X-100 was used as a chemical modifier. Accuracy was verified using a tuna fish certified reference material (CRM BCR 627), with statistically equivalent concentrations (Student's $t$-test) for both total As and AsB.

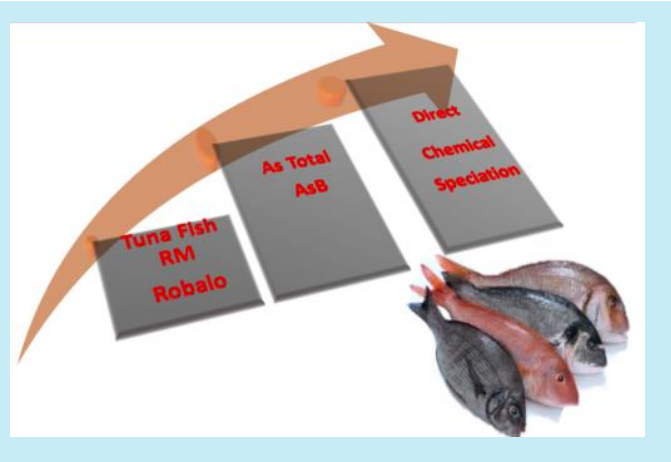

\section{Introduction}

Marine organisms have been intensively used as bioindicators for ecological risk assessment, enabling the monitoring of potentially toxic elements, such as arsenic (As), which provides information about the risk of human contamination ${ }^{1}$. Consequences of exposure to As in humans include progressive deterioration in motor and sensory responses, problematic pregnancy outcomes, cardiovascular disease and skin hyperpigmentation, as well as lung, skin and bladder cancer, and even death ${ }^{2,3}$. However, the toxicity of As depends on its chemical species. The most toxic As species present in marine organisms are the arsenite $(\mathrm{As}(\mathrm{III}))$ and arsenate $(\mathrm{As}(\mathrm{V}))$, followed by the methylated (MMA) and dimethylated (DMA) forms ${ }^{1}$. Although fishes can contribute with up to $90 \%$ of all arsenic exposure originated from food, only a low portion of this element is present in its inorganic form. This is related to the presence of large amount of arsenobetaine (AsB), which is a relatively nontoxic form of arsenic. In general, AsB correspond to $80-90 \%$ of As in fish ${ }^{1,4,5}$.

Taking into consideration that different As species induce different toxicity levels, some countries have established regulations for inorganic As content in food. China, for example, set maximum inorganic As levels for inspection of aquatic products (fish and products from fish, with the exception of live fishes). In this case, inorganic 
arsenic (iAs) was regulated to a maximum of 0.01 $\mathrm{mg} \mathrm{kg}^{-1}$ and $0.5 \mathrm{mg} \mathrm{kg}^{-1}$ for finfish and other fishes, respectively ${ }^{6}$. The maximum level of iAs in marine organisms was also regulated by Australia and was set as 2.0, 2.0, 1.0 and $1.0 \mathrm{mg} \mathrm{kg}^{-1}$ for crustaceans, fish, shellfish, and algae, respectively ${ }^{7}$. The European Union has not established legislation to limit of the arsenic species in marine organisms but recommends the monitoring of iAs levels in fish feed, algae and animal feed. In this case, the maximum iAs content recommended is $2 \mathrm{mg} \mathrm{kg}^{-18,9}$.

The determination of total arsenic concentration can be performed using many analytical techniques. Although As speciation has been frequently reported in the literature, incorrect results are not uncommon. The errors are generally related to the matrix complexity and the wide variety of materials that are routinely analyzed. This problem becomes even more evident when analyses of samples with low analyte content are required. One way to ensure the quality of analytical results in this case is the use of reference materials (RMs), which allow the assessment of the method accuracy and ensure the quality of the analytical results. Additionally, RMs are also used for instrument calibration, especially when direct solid sampling techniques are required ${ }^{10,11}$.

According to the COMAR database (International database of certified reference materials) ${ }^{12}$, the development of new RMs has been continually growing, because of the market development and the production of new industrial materials. The demand of RMs for speciation analyses has been also increasing, especially the ones dedicated to do the screening and identification of toxic and non-toxic species ${ }^{13,14}$. Generally, speciation analyses are based on chromatographic methods with, including liquid chromatography coupled to inductively coupled plasma mass spectrometry (LC-ICP-MS), which remains the main choice for arsenic species determination ${ }^{15,16,17}$.

The use of instrumental neutron activation analysis (INAA) to As detecting has been used to validate As species mass fractions combined with LC-ICP-MS ${ }^{14}$. It was demonstrated by the results that INAA can account for $100 \%$ of arsenic species distribution in analytical processes, complementing LC-ICP-MS technique in validation of the As species characterization in the development of RMs to such chemicals species.
The sample preparation for speciation analysis is generally a crucial and laborious step, as interconversion, losses or degradation of species must be avoided. The use of direct solid sampling in graphite furnace atomic absorption spectrometry (GF AAS) can be a good alternative to avoid or minimize the sample treatment step $^{18,19}$. In this case, the use of different chemical modifiers and/or different heating program conditions may result in the measurement of different species ${ }^{20}$.

Recently, some studies have used electrothermal atomic absorption spectrometry (ET AAS) for As(III), As(V), MMA, DMA and AsB speciation in fish-based foods ${ }^{20-25}$. Significant differences were reported for the atomization of $\mathrm{iAs}$ and $\mathrm{AsB}$ or arsenocholine (AC) when using different chemical modifiers. These studies have shown evidence that the behavior of these species in the atomizer is different and depends on the chemical modifier used for the measurements ${ }^{20}$.

López-García and co-workers have developed a method to measure iAs (As(III) and As(V)), MA, DMA and AsB in fish-based baby foods by ET AAS, using slurries prepared in tetramethylammonium hydroxide (TMAH) solution and a chemical modifier based on palladium salt, which was used for total As determination, whereas a chemical modifier based on $\mathrm{Ce}(\mathrm{IV})$ was used for determination of inorganic arsenic (As(III) and As(V)) + MA. The authors also used a zirconium coated atomizer for determination of DMA and $\mathrm{AsB}^{25}$

In this context, the present work aimed to develop a simple procedure for direct measurement of total As and some As species by SLS-GF AAS. Direct chemical speciation of As in tuna fish (RM) and robalo liver prepared in our laboratory was evaluated using different masses of $\mathrm{Pd}$ and $\mathrm{Mg}$ as chemical modifier solutions. The results found in this work were compared to those obtained for the same samples by INAA and LC-ICP-MS in a previous work ${ }^{14}$. The accuracy of the proposed method was also verified using tuna fish certified reference material (CRM) BCR 627 from the Institute for Reference Materials and Measurements (IRMM, Belgium). 


\section{Materials and methods}

\subsection{Instrumentation}

The measurement of arsenic species was carried out using a Model ZEEnit 60 atomic absorption spectrometer (Analytik Jena AG, Jena, Germany), equipped with a hollow arsenic cathode lamp, a transverse heated graphite tube atomizer, and a Zeeman background corrector. Pyrolytically coated transverse heated graphite tubes and pyrolytically coated boat-type solid sampling platforms (Analytik Jena) were used throughout. A manual solid sampling accessory (SSA-6 Z, Analytik Jena AG, Germany) with pre-adjusted micro-tweezers was used to transfer the boat-type platform to the graphite tube. For purging and protection gas, argon $(99.998 \%$, v/v; Air Liquide Brazil, São Paulo, Brazil) was used. Table 1 presents the instrumental parameters used after optimizing the pyrolysis temperature.

Table 1. Instrumental parameters, experimental conditions, and heating program used in the total and direct chemical speciation of arsenic by SLS-GF AAS.

\begin{tabular}{|c|c|c|c|c|}
\hline \multicolumn{5}{|c|}{ Instrumental parameters } \\
\hline Wavelength & & & & $193.7 \mathrm{~nm}$ \\
\hline Slit & & & & $0.8 \mathrm{~nm}$ \\
\hline Lamp current & & & & $6 \mathrm{~mA}$ \\
\hline \multicolumn{5}{|c|}{ Heating program for total As determination by SLS-GF AAS } \\
\hline Step & Temperature $/{ }^{\circ} \mathrm{C}$ & $\mathrm{Ramp} /{ }^{\circ} \mathrm{C} \mathrm{s}^{-1}$ & Hold time/s & Ar Flow/L $\min ^{-1}$ \\
\hline Drying & 130 & 10 & 20 & 1.0 \\
\hline Pyrolysis & 1200 & 100 & 40 & 1.0 \\
\hline Atomization & 2500 & 2600 & 6 & 0 \\
\hline Cleaning & 2600 & 1200 & 3 & 1.0 \\
\hline
\end{tabular}

A freeze-dryer (Thermo Electron Corporation), a food cutting mill (GM 200 model, Retsch, Germany) and a cryogenic mill with a selfcontained liquid nitrogen bath (MA 775 model, Marconi, Brazil) were used for preparation of tuna fish candidate reference material.

\subsection{Reagents and materials}

All solutions were prepared using high-purity deionized water obtained from a Milli-Q water purification system (Millipore, Bedford, MA, USA). Analytical reference solutions of As were prepared by successive dilutions of a stock solution containing $1000 \mathrm{mg} \mathrm{L}^{-1} \mathrm{As}(\mathrm{III})$ and As(V) (SigmaAldrich, Germany) and analytical reference solutions of AsB were prepared from stock solutions containing $200 \mathrm{mg} \mathrm{L}^{-1}$ AsB (Sigma Aldrich, Brazil).

Solutions of $10 \mathrm{~g} \mathrm{~L}^{-1} \mathrm{Pd}\left(\mathrm{NO}_{3}\right)_{2}$ (Suprapur, Merck) and $10 \mathrm{~g} \mathrm{~L}^{-1} \mathrm{Mg}\left(\mathrm{NO}_{3}\right)_{2}$ (Suprapur, Merck) were used to prepare the chemical modifier solutions. Triton X-100 (Merck) was added to the chemical modifier solution $(0.1 \% \mathrm{w} / \mathrm{v})$.

Calibration analytical curves for total As determination were obtained by using reference solutions with concentrations between 5.0 and
$100.0 \mu \mathrm{g} \mathrm{L}^{-1}$ of $\mathrm{As}(\mathrm{III})$ in TMAH $0.2 \%(\mathrm{v} / \mathrm{v})$ or $\mathrm{HNO}_{3} 0.1 \%(\mathrm{v} / \mathrm{v})$. Calibration analytical curves for AsB determination were obtained using analytical solutions with concentrations between 12 and $240 \mu \mathrm{g} \mathrm{L}^{-1} \mathrm{AsB}$ in $0.1 \% \mathrm{v} / \mathrm{v} \mathrm{HNO}_{3}$

\subsection{Samples}

Tuna fish candidate RM and robalo liver were collected at a fish market in São Paulo (Brazil) and prepared according to the procedure described by Carioni et al. ${ }^{26}$ and Naozuka and Nomura ${ }^{27}$. Briefly, the tissue was separated, cleaned with deionized water, cut into $2 \mathrm{~cm}^{3}$ pieces, frozen and freeze-dried for $48 \mathrm{~h}$. The milling of the dried samples was performed using a cutting mill for $3 \mathrm{~min}$ at 5,000 rpm, followed by cryogenic milling (5 min of freezing followed by 3 cycles of $2 \mathrm{~min}$ of grinding, with $1 \mathrm{~min}$ of freezing between each cycle). The resulting final product was radiationsterilized, bottled, and stored.

Tuna fish certified reference material (CRM $B C R$ 627) from the Institute for Reference Materials and Measurements (IRMM, Belgium) was used to check the accuracy of the methods developed for measurement of As species and total As mass fraction. 


\subsection{Procedures}

\subsubsection{Evaluation of pyrolysis temperature}

Pyrolysis temperature curves were evaluated in the absence and presence of two different chemical modifiers: $5 \mu \mathrm{g} \mathrm{Pd}+3 \mu \mathrm{g} \mathrm{Mg}+0.1 \% \mathrm{w} / \mathrm{v}$ Triton $\mathrm{X}-100$ and $25 \mu \mathrm{g} \mathrm{Pd}+15 \mu \mathrm{g} \mathrm{Mg}+0.1 \% \mathrm{w} / \mathrm{v}$ Triton $\mathrm{X}-100$. The temperature was evaluated in a range of $180-1600{ }^{\circ} \mathrm{C}$ using increments of $20^{\circ} \mathrm{C}$. Slurries were prepared for this purpose using the procedure described by López-García, Briceño and Hernández-Córdoba ${ }^{25}$ with modifications in the mass of tuna fish and TMAH concentration. Briefly, the slurries were prepared using $100 \mathrm{mg}$ of tuna fish candidate reference material in $5.0 \mathrm{~mL}$ of TMAH $0.2 \%(\mathrm{v} / \mathrm{v})^{25}$.

\subsubsection{Sample preparation for total As and species determination}

Slurries were prepared using $100 \mathrm{mg}$ of sample, $5.0 \mathrm{ml}$ of $\mathrm{H}_{2} \mathrm{O}$ and agitation in Vortex (Quimis, Q220, Diadema, São Paulo) at $25^{\circ} \mathrm{C}$. Before each measurement, the sample slurry was homogenized using a pipette and then aliquots of $20 \mu \mathrm{L}$ were injected into the atomizer together with $10 \mu \mathrm{l}$ of different chemical modifiers: $5 \mu \mathrm{g} \mathrm{Pd}+3 \mu \mathrm{g} \mathrm{Mg}+$ $0.1 \%$ w/v Triton X-100, $25 \mu \mathrm{g} \mathrm{Pd}+15 \mu \mathrm{g} \mathrm{Mg}+$ $0.1 \% \mathrm{w} / \mathrm{v}$ Triton X-100 or $100 \mu \mathrm{g} \mathrm{Pd}+0.1 \% \mathrm{w} / \mathrm{v}$ Triton $\mathrm{X}-100$. The heating program optimized for the analysis is presented in Table 1. Analytical calibration curves were obtained using solutions containing different $\mathrm{As}(\mathrm{III})$ concentrations (5.0 and $100.0 \mu \mathrm{g} \mathrm{L}^{-1}$ ) prepared in $0.1 \% \mathrm{v} / \mathrm{v} \mathrm{HNO}_{3}$.

\section{Results and discussion}

\subsection{Heating program optimization}

The pyrolysis temperature was evaluated in order to find the best conditions for measurement of total As and AsB species by SLS-GF AAS. Triton X-100 was used in combination with Pd + $\mathrm{Mg}$ to improve the interaction between the solid sample and the chemical modifier solution ${ }^{28}$.

Figure 1 shows the pyrolysis temperature curves obtained for tuna fish slurry in TMAH media. The atomization, drying, and cleaning temperatures were used according to Carioni et $a l .^{26}$.

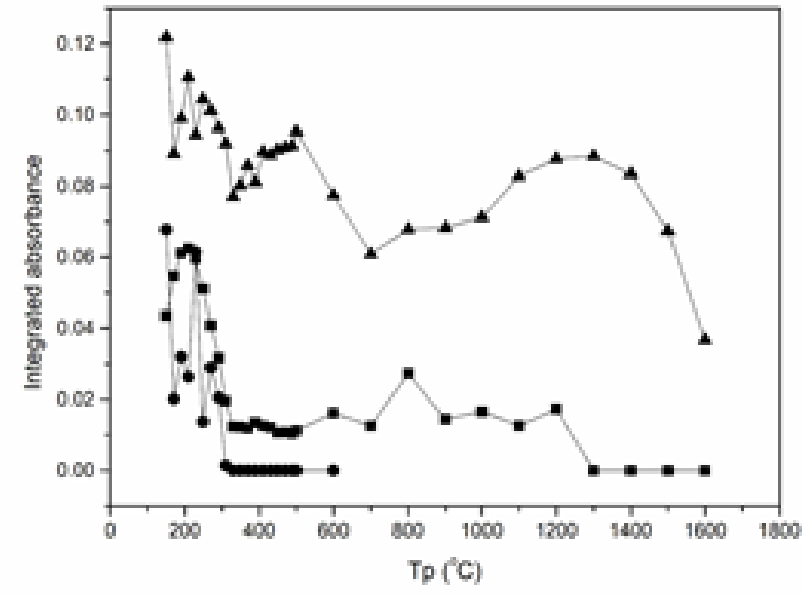

Figure 1. Pyrolysis temperature curves for slurry tuna fish candidate reference material in TMAH (•) in the absence of chemical modifiers, $(\boldsymbol{\square})$ in the presence of 5 $\mu \mathrm{g} \mathrm{Pd}+3 \mu \mathrm{g} \mathrm{Mg}+0.1 \% \mathrm{w} / \mathrm{v}$ Triton X-100, ( $\boldsymbol{\Delta})$ in the presence of $25 \mu \mathrm{g} \mathrm{Pd}+15 \mu \mathrm{g} \mathrm{Mg}+0.1 \% \mathrm{w} / \mathrm{v}$ Triton X100.

In the absence of chemical modifiers As was lost by volatilization at temperatures higher than 300 ${ }^{\circ} \mathrm{C}$. However, in the presence of chemical modifiers, higher masses of $\mathrm{Pd}$ and $\mathrm{Mg}$ resulted in higher sensitivity, and the best pyrolysis temperature was $1200{ }^{\circ} \mathrm{C}$ for both modifier solutions. We observed that different pyrolysis curve profiles were obtained when $5 \mu \mathrm{g} \mathrm{Pd}+3 \mu \mathrm{g}$ $\mathrm{Mg}+0.1 \% \mathrm{w} / \mathrm{v}$ Triton $\mathrm{X}-100$ was used in comparison with $25 \mu \mathrm{g} \mathrm{Pd}+15 \mu \mathrm{g} \mathrm{Mg}+0.1 \% \mathrm{w} / \mathrm{v}$ Triton X-100. In this case, the mass of chemical modifiers may have an impact on the atomization mechanism of some As species present in the candidate RM used for this study. This hypothesis was further investigated in this work.

Using $25 \mu \mathrm{g} \mathrm{Pd}+15 \mu \mathrm{g} \mathrm{Mg}+0.1 \%$ w/v Triton $\mathrm{X}-100$ as chemical modifiers at the pyrolysis temperature of $1200{ }^{\circ} \mathrm{C}$, analytical calibration curves prepared in the presence of $0.2 \%$ of TMAH $(\mathrm{v} / \mathrm{v})$ were compared to those prepared in the presence of $0.1 \%$ of $\mathrm{HNO}_{3}(\mathrm{v} / \mathrm{v})$ to determine the chemical interference promoted by these reagents. Thus, the slopes and correlation coefficients of those calibration curves were respectively 0.0023 and 0.9998 for the curve prepared in the presence of $0.1 \%$ of $\mathrm{HNO}_{3}$ and 0.0022 and 0.9993 for the curve prepared in the presence of $0.2 \%$ of TMAH. The slope ratio between both calibration curves was 1.05, showing no significant effect of TMAH on As measurement enabling the use of $0.1 \%$ $\mathrm{HNO}_{3}$ media for further analytical calibration curves preparation. 
The integrated absorbance signals of As at the optimized heating program were also compared in samples slurries prepared in 0.2\% TMAH with those prepared using only $\mathrm{H}_{2} \mathrm{O}$. No significant difference (Student's $t$-test 95\% level) was found between those solutions, suggesting the use of TMAH is not imperative. For this reason, slurries prepared in $\mathrm{H}_{2} \mathrm{O}$ were used for further analysis.

\subsection{Total As determination and direct chemical speciation}

Thermal behavior of total As and As species in tuna fish tissue and robalo liver in the absence and in the presence of chemical modifiers were investigated. Significant difference was observed in the results for As concentration when $5 \mu \mathrm{g} \mathrm{Pd}+$ $3 \mu \mathrm{g} \mathrm{Mg}+0.1 \% \mathrm{w} / \mathrm{v}$ Triton $\mathrm{X}-100$ was compared with $25 \mu \mathrm{g} \mathrm{Pd}+15 \mu \mathrm{g} \mathrm{Mg}+0.1 \%$ w/v Triton X100. When masses of $\mathrm{Pd}$ and $\mathrm{Mg}$ were increased by a factor of 5, the results were $1.3-1.2$ times higher. In addition, the values obtained for a fish tissue CRM after using the $5 \mu \mathrm{g} \mathrm{Pd}+3 \mu \mathrm{g} \mathrm{Mg}+0.1 \%$ w/v Triton X-100 and $25 \mu \mathrm{g} \mathrm{Pd}+15 \mu \mathrm{g} \mathrm{Mg}+0.1 \%$ w/v Triton X-100 as chemicals modifiers corresponded to the certified values for AsB and total As, respectively (Table 2). Results for total As tuna fish candidate reference material were also in agreement (Student's $t$-test, $\mathrm{p}>0.05$ ) with previous results obtained by our group using SS-GFAAS $\left(4.8 \pm 0.2 \mathrm{mg} \mathrm{kg}^{-1}\right)^{26}$ and INAA $(5.1 \pm 0.1 \mathrm{mg}$ $\left.\mathrm{kg}^{-1}\right)^{14}$.

Table 2. Results of As mass fractions obtained for Tuna Fish certified reference materials (BCR 627) and Tuna fish candidate reference material for Arsenobetaine $(\mathrm{AsB})^{\mathrm{a}}$ and Total Arsenic $\left(\right.$ AsT) ${ }^{\mathrm{b}}$ by SLS-GF AAS, $\mathrm{n}=3$.

\begin{tabular}{cccccc}
\hline Concentration/mg kg & -1 \\
\hline & $\begin{array}{c}\text { Certified value } \\
\text { (BCR 627) }\end{array}$ & $\begin{array}{c}\text { Measured value } \\
\text { (BCR 627) }\end{array}$ & CV (\%) & $\begin{array}{c}\text { Tuna fish } \\
(\mathrm{RM})\end{array}$ & $\mathrm{CV}(\%)$ \\
\hline $5 \mu \mathrm{g} \mathrm{Pd}+3 \mu \mathrm{g} \mathrm{Mg}+$ Triton* & $3.9 \pm 0.2^{\mathrm{a}}$ & $3.5 \pm 0.2$ & 5.4 & $3.6 \pm 0.4$ & 11.9 \\
$25 \mu \mathrm{g} \mathrm{Pd}+15 \mu \mathrm{gg} \mathrm{Mg}+$ & $4.8 \pm 0.3^{\mathrm{b}}$ & $4.5 \pm 0.3$ & 5.8 & $4.4 \pm 0.3$ & 5.9 \\
Triton* & & & &
\end{tabular}

*0.1\% w/v Triton X-100

Results obtained for As content in tuna fish candidate reference material (Table 2) using the 5 $\mu \mathrm{g} \mathrm{Pd}+3 \mu \mathrm{g} \mathrm{Mg}+0.1 \% \mathrm{w} / \mathrm{v}$ Triton X-100 chemical modifier corresponded to the certified value of AsB (Student's $t$-test, $\mathrm{p}>0.05$ ). The results for $\mathrm{AsB}$ in tuna fish candidate reference material (Table 2) are also in agreement with a previous work $\left(3.99 \pm 0.08 \mathrm{mg} \mathrm{kg}^{-1}\right)$, when the same sample was analyzed by HPLC-ICP-MS ${ }^{14}$. In this study, we observed that differences in the behavior of As species, when atomized in the presence of different chemical modifiers, allowed the direct speciation of AsB by SLS-GF AAS. The dependence of As atomization on the chemical modifier have already been reported in previous works $^{25,29}$. Differences in the behavior of organic and inorganic arsenic were observed when solutions containing different composition and/or masses of chemical modifiers were used ${ }^{25,29}$.

Although the proposed procedure did not allow the discrimination of other As species in fish, AsB could be separated from the toxic As species DMA and other unknown As species. DMA is also a constituent of tuna fish tissue and its presence was reported in the tuna fish SRM $627^{30}$.
The same procedure used for determination of total As in tuna fish was applied to robalo liver. The obtained result $\left(6.9 \pm 0.8 \mathrm{mg} \mathrm{kg}^{-1}\right)$ was not in agreement with a previous work in which total As in the same sample was determined by INAA ( 11.0 $\left.\pm 0.2 \mathrm{mg} \mathrm{kg}^{-1}\right)^{14}$. This problem can be the result of different As species in robalo liver, which may result in a different mechanisms of atomization. The As species in robalo liver are still unknown, although some evidences have shown that part of As is likely present in the form of arsenolipids ${ }^{14}$. The difference in the behavior of As species was discussed in a recent work by Pereira and coworkers ${ }^{29}$. Their work has identified differences in pyrolysis curves from As(III) aqueous solutions and As in fish oil when $\mathrm{Pd}+\mathrm{Ru}$ were used as chemical modifiers, which may be related to the presence of other As species besides of As(III), such as arsenolipids.

When $100 \mu \mathrm{g} \mathrm{Pd}+0.1 \%$ w/v Triton X-100 was used as a chemical modifier, better recovery was obtained. In this condition, the value obtained for total As $\left(10.3 \pm 0.6 \mathrm{mg} \mathrm{kg}^{-1}\right)$ is in agreement with the literature ${ }^{14}$. This indicates that the composition of the chemical modifier should be adjusted for each sample, since the atomization mechanism for 
total As determination was clearly altered by matrix constituents. In addition, the use of a sufficient mass of the chemical modifiers allowed the measurement of total As content in the slurries, irrespective of the chemical species in which it is present $^{25,26}$.
The detection and quantification limits and characteristic masses are shown in Table 3, using the three different chemical modifiers. These detection limits are appropriate for the determination of these species, avoiding the need of extraction processes and/or chromatographic separations $\mathrm{s}^{25}$.

Table 3. Analytical parameters of SLS-GF AAS for total and direct chemical speciation of arsenic.

\begin{tabular}{cccc}
\hline & $5 \mu \mathrm{g} \mathrm{Pd}+3 \mu \mathrm{g} \mathrm{Mg}+$ Triton* & $25 \mu \mathrm{g} \mathrm{Pd}+15 \mu \mathrm{g} \mathrm{Mg}+$ Triton & $100 \mu \mathrm{g} \mathrm{Pd}+$ Triton \\
\hline $\operatorname{LOD}\left(\mu \mathrm{g} \mathrm{kg}^{-1}\right)$ & 34.6 & 19.9 & 18.5 \\
$\operatorname{LOQ}\left(\mu \mathrm{g} \mathrm{kg}^{-1}\right)$ & 103.9 & 59.9 & 55.5 \\
$m_{o}{ }^{\mathrm{a}}(\mathrm{pg})$ & 35 & 33 & 34
\end{tabular}

$\mathrm{LOD}=\left(3 \times \mathrm{SD}_{\mathrm{bco}} \mathrm{b} / \mathrm{slope}\right), \mathrm{LOQ}=(3 \times \mathrm{LOD}),{ }^{\mathrm{a}} m_{o}=$ characteristic mass $(1 \%$ absorbance or 0.0044 absorbance signal $)$, ${ }^{\mathrm{b}} \mathrm{SD}_{\mathrm{bco}}=$ standard deviation of blank $(\mathrm{n}=10)$.

$* 0.1 \%$ w/v Triton X-100.

When $5 \mu \mathrm{g} \mathrm{Pd}+3 \mu \mathrm{g} \mathrm{Mg}+0.1 \%$ w/v Triton X100 was used for As determination in robalo liver, $5.1 \pm 0.2 \mathrm{mg} \mathrm{kg}^{-1}$ of As was measured. The identification of As species, however, remains to be elucidated. Previous analyses have demonstrated poor results for As speciation in this samples when extractions were performed using methanol $/ \mathrm{H}_{2} \mathrm{O}$ and acetone/methanol/ $\mathrm{H}_{2} \mathrm{O}$ (44 and $49 \%$ of total As, respectively). The high amount of lipids in this kind of sample may prevent the extraction of part of the As to the aqueous phase, preventing the identification of As species ${ }^{14}$. In view of these analytical difficulties, more investigations on the quantification and identification of the different arsenic species are still required for robalo liver.

In summary, the direct total As and As speciation methods for tuna fish were performed by a simple slurry preparation in water, using aqueous calibration. In the case of total As, there was no need of digestion and dilution steps when the chemical modifiers were used for tuna fish and robalo liver analysis. In the case of determination of AsB, the use of $5 \mu \mathrm{g} \mathrm{Pd}+3 \mu \mathrm{g} \mathrm{Mg}+0.1 \% \mathrm{w} / \mathrm{v}$ Triton X-100 as a chemical modifier allowed the direct measurement of this As compound in tuna fish without prior separation of species. It implies that all laborious steps of extraction, centrifugation and separation were not necessary. Considering that tuna fish is extensively consumed by many populations in the world, the present study represents a valuable tool for the assessment of non-toxic As species, which brings the possibility to assure the safety of tuna consumers using two simple complementary methods to distinguish AsB from other As compounds in tuna fish.

\section{Conclusions}

This work described the use of different chemical modifier compositions for the development of a direct speciation method for AsB measurement in tuna fish tissue by SLS-GF AAS. Methods for total As measurements in tuna fish and robalo liver were also evaluated.

The direct determination of AsB was achieved when a solution containing $5 \mu \mathrm{g} \mathrm{Pd}+3 \mu \mathrm{g} \mathrm{Mg}+$ $0.1 \% \mathrm{w} / \mathrm{v}$ Triton $\mathrm{X}-100$ was used as chemical modifier in tuna fish tissue. The use of $25 \mu \mathrm{g} \mathrm{Pd}+$ $15 \mu \mathrm{g} \mathrm{Mg}+0.1 \%$ w/v Triton X-100 and $100 \mu \mathrm{g} \mathrm{Pd}$ $+0.1 \% \mathrm{w} / \mathrm{v}$ Triton X-100 allowed the total As measurement in tuna fish tissue and robalo liver, respectively. This work demonstrated that the behavior of arsenic in SLS-GF AAS may depend on the species of the element and composition or concentration of chemical modifiers. In addition, the simplicity of the proposed method enables its use for routine analyses as a valuable tool for quality control of tuna in the fishing industry.

\section{Acknowledgments}

The authors acknowledge the support of the Fundação de Amparo à Pesquisa do Estado de São Paulo for financial support (FAPESP no. 2007/56504-6, 2012/11998-0, 2017/10346-2) and 
Conselho Nacional de Desenvolvimento Científico e Tecnológico (CNPq) for financial support and fellowships.

\section{References}

[1] Leermakers, M., Baeyens, W., De Gieter M., Smedts, B., Meert, C., De Bisschop, H. C., Morabito, R., Quevauviller, P., Toxic arsenic compounds in environmental samples: Speciation and validation, Trends Anal. Chem. 25 (1) (2006) 1-10. https://doi.org/10.1016/j.trac.2005.06.004.

[2] Shakoor, M. B., Nawaz, R., Hussain, F., Raza, M., Ali, S., Rizwan, M., Oh, S., Ahmad, Human health implications, risk assessment and remediation of Ascontaminated water: A critical review, Sci. Total Environ. 601-602 (2017) 756-769. https://doi.org/10.1016/j.scitotenv.2017.05.223.

[3] Yunus, F. M., Khan, S., Chowdhury, P., Milton, A. H., Hussain, S., Rahman, M., A review of groundwater arsenic contamination in Bangladesh: the millennium development goal era and beyond, Int. J. Environ. Res. Public Health. 13 (215) (2016) 1-18. https://doi.org/10.3390/ijerph13020215.

[4] McSheehy, S., Szpunar, J., Morabito, R., Quevauviller, P., The speciation of arsenic in biological tissues and the certification of reference material for quality control, Trends Anal. Chem. 22 (4) (2003) 191209. https://doi.org/10.1016/S0165-9936(03)00404-7.

[5] Ysart, G., Miller, P., Croasdale, M., Crews, H., Robb, P., Baxter, M., L’Argy, C., Harrison, N., 1997 UK total diet study: aluminium, arsenic, cadmium, chromium, copper, lead, mercury, nickel, selenium, tin and zinc, Food Addit. Contam. 17 (9) (2000) 775-786. https://doi.org/10.1080/026520300415327.

[6] Cfia - Canadian Food Inspection Agency, Certification Requirements: China, 2017. http://www.inspection.gc.ca/food/fish-and-

seafood/exports/by-

jurisdiction/china/eng/1373555071317/1373555185449

[7] Comlaw, Australia New Zealand Food Standards Code: Standard 1.4.1: Contaminants and Natural Toxicants.

http://www.comlaw.gov.au/details/f2011c00121.

[8] Pétursdóttir, Á. H., Gunnlaugsdóttir, H., Jörundsdóttir, H., Raab, A., Krupp, E. M., Feldmann, J., Determination of inorganic arsenic in seafood: Emphasizing the need for certified reference materials,
Pure Appl Chem. 84 (2) (2012) 191-202. https://doi.org/10.1351/PAC-CON-11-10-03.

[9] The Commission of the European Communities, Commission directive 2009/141/EC of 23 November 2009 - amending Annex I to Directive 2002/32/EC of the European Parliament and of the Council as regards maximum levels for arsenic, theobromine, Datura sp., Ricinus communis L., Croton tiglium L. and Abrus precatorius $\quad$ L. http://eur-lex.europa.eu/legalcontent/EN/ALL/?uri=CELEX\%3A32009L0141.

[10] ABNT, Associação Brasileira de Normas Técnicas, "Termos e definições relacionados com materiais de referência", 1 ed. Rio de Janeiro, 2000a (ABNT ISO Guia 30).

[11] Zschunke, A., The role of reference materials in analytical chemistry, Accred. Qual. Assur. 8 (2003) 247 251.

[12] Comar - International database for certified reference materials. http://www.comar.bam.de/en/. Accessed July 20, 2018.

[13] Chelegão, R., Carioni, V.M.O., Naozuka, J., Nomura, C. S., Feasibility of using AAS for the characterization of a tuna fish candidate reference material for total $\mathrm{Hg}$ and methyl- $\mathrm{Hg}$ measurement, $\mathrm{J}$. Braz. Chem. Soc. 27 (4) (2016) 712-718. https://doi.org/10.5935/0103-5053.20150320.

[14] Carioni, V. M. O., Nomura, C. S., Yu, L. L., Zeisler, R., Use of neutron activation analysis and LC-ICP-MS in the development of candidate reference materials for As species determination, J. Radioanal. Nucl. Chem. 299 (2014) 241-248. https://doi.org/10.1007/s10967013-2790-6.

[15] Fang, Y., Pan, Y., Li, P., Xue, M., Pei, F., Yang, W., Maa, N., Hua, Q., Simultaneous determination of arsenic and mercury species in rice by ion-pairing reversed phase chromatography with inductively coupled plasma mass spectrometry, Food Chem. 213 (2016) 609-615. https://doi.org/10.1016/j.foodchem.2016.07.003.

[16] Jia, X., Gong, D., Wang, J., Huang, F., Duan, T., Zhang, X., Arsenic speciation in environmental waters by a new specific phosphine modified polymer microsphere preconcentration and HPLC-ICP-MS determination, Talanta. 160 (2016) 437-443. https://doi.org/10.1016/j.talanta.2016.07.050.

[17] Kalantzi, I., Mylona, K., Sofoulaki, K., Tsapakis, M., Pergantis, S.A., Arsenic speciation in fish from Greek coastal areas, J. Environ. Sci. (2017). https://doi.org/10.1016/j.jes.2017.03.033. 
[18] Cornelis, R., Crews, H., Caruso, J., Heumann, K.G., Handbook of Elemental Speciation II: Species in the Environment, Food, Medicine \& Occupational Health, John Wiley \& Sons, 2005, p. 488.

[19] Nomura, C. S., Silva, C. S., Nogueira, A. R. A., Oliveira P. V., Bovine liver sample preparation and micro-homogeneity study for $\mathrm{Cu}$ and $\mathrm{Zn}$ determination by solid electrothermal atomic absorption spectrometry, Spectrochim. Acta Part B. 60 (5) (2005) 673-680. https://doi.org/10.1016/j.sab.2005.02.021.

[20] Anawar, H. M., Arsenic speciation in environmental samples by hydride generation and electrothermal atomic absorption spectrometry, Talanta 88 (2012) 30-42. https://doi.org/10.1016/j.talanta.2011.11.068.

[21] Serafimovski, I., Karadjova, I. B., Stafilov, T., Tsalev, D. L., Determination of total arsenic and toxicologically relevant arsenic species in fish by using electrothermal and hydride generation atomic absorption spectrometry, Microchem. J. 83 (2006) 5560. https://doi.org/10.1016/j.microc.2006.01.021.

[22] Shah, A. Q., Kazi, T. G., Baig, J. A., Arain, M. B., Afridi, H. I., Kandhro, G. A., Wadhwa, S. K., Kolachi, N. F., Determination of inorganic arsenic species $\left(\mathrm{As}^{3+}\right.$ and $\mathrm{As}^{5+}$ ) in muscle tissues of fish species by electrothermal atomic absorption spectrometry (ETAAS), Food Chem. 119 (2010) 840-844. https://doi.org/10.1016/j.foodchem.2009.08.041.

[23] Zmozinski, A. V., Llorente-Mirandes, T., Damin, I. C. F., López-Sánchez, J. F., Vale M. G. R., Welz, B., Silva, M. M., Direct solid sample analysis with graphite furnace atomic absorption spectrometry-A fast and reliable screening procedure for the determination of inorganic arsenic in fish and seafood, Talanta. 134 (2015) 224-231. https://doi.org/10.1016/j.talanta.2014.11.009.

[24] Mihucz, V. G., Bencs, L., Koncz, K., Tatár, E., Weiszburg, T., Záray, G., Fast arsenic speciation in water by onsite solid phase extraction and highresolution continuum source graphite furnace atomic absorption spectrometry, Spectrochimica Acta Part B: Atomic Spectroscopy. (2017). https://doi.org/10.1016/j.sab.2016.12.010.

[25] López-García, I., Briceño, M., HernándezCórdoba, M., Non-chromatographic screening procedure for arsenic speciation analysis in fish-based baby foods by using electrothermal atomic absorption spectrometry, Anal. Chim. Acta, 699 (2011) 11-17. https://doi.org/10.1016/j.aca.2011.05.005.
[26] Carioni, V. M. O, Chelegão, R., Naozuka, J., Nomura, C. S., Feasibility study for the preparation of a tuna fish candidate reference material for total As determination, Accred. Qual. Assur. 16 (2011) 453-458. https://doi.org/10.1007/s00769-011-0796-8.

[27] Naozuka, J., Nomura, C. S., Total determination and direct chemical speciation of $\mathrm{Hg}$ in fish by solid sampling GF AAS, J. Anal. At. Spectrom. 26 (2011) 2257-2262. https://doi.org/10.1039/C1JA10188A.

[28] Naozuka, J., Oliveira, P. V., Minimization of Sample Pretreatment for $\mathrm{Al}, \mathrm{Cu}$ and Fe Determination in Coconut Water by Electrothermal Atomic Absorption Spectrometry, J. Braz. Chem. Soc. 17 (2006) 521-526. https://doi.org/10.1590/S0103-50532006000300014.

[29] Pereira, E. R., Almeida, T. S., Borges, D. L. G., Carasek, E., Welz, B., Feldmann, J., Menoyo, J. C., Investigation of chemical modifiers for the direct determination of arsenic in fish oil using high-resolution continuum source graphite furnace atomic absorption $\begin{array}{lllll}\text { spectrometry, Talanta } & 150 & \text { (2016) } & \text { 142-147. }\end{array}$ https://doi.org/10.1016/j.talanta.2015.12.036.

[30] Maier, E. A., Demesmay, C., Olle, M., Lamotte, A., Lagarde, F., Heimburger, R., Leroy, M. J. F., Asfari, Z., Muntau, H., The certification of the contents (mass fractions) of arsenobetaine in solution (CRM 626) and of total arsenic, arsenobetaine, dimethylarsinic acid in tuna fish tissue (CRM 627), Luxembourg: Office for Official Publications of the European Communities, 1997. 